training research workers, aeronautical engineers and other technicians are under continuous review by the Technical Personnel Committee. It is agreed that men with postgraduate research and similar qualifications should not be allowed to enter the Forces, except for special commissioned posts, for example, operational research. The allocation and deferment arrangements of the Ministry of Labour are considered to provide ample safeguards for this purpose. A professional engineering or scientific qualification is, however, essential for many commissioned posts in the Fighting Services, and in view of the recommendations of Sir William Beveridge's Committee on the Use of Skilled Men in the Services, it has been recognized that a substantial proportion of technical officers in the Services in charge of maintenance and repair of equipment should possess technical qualifications of a university degree or professional standard together with extensive practical experience. But the numbers thus made available were insufficient. It has therefore been necessary to allocate a substantial proportion of the university output to the Services, and also to withdraw experienced men from industry; many of the latter have been volunteers, and the Ministry is concerned lest the Select Committee's observations should be misunderstood, with unfortunate effect on such volunteering.

Steps have also been taken to increase the supply of men graduating in technical subjects by means of the State bursaries, the intensive Higher National Certificate and the Engineering Cadetship schemes. Courses at universities have keen shortened to a maximum of two years and three months (two years and nine months in Scotland), and by these measures the output has been substantially increased since 1941 and will reach a peak in 1944. In view of these shortened courses, the Technical Personnel Committee considers that specialized pre-graduate aeronautical courses could be extended only at the expense of fundamental engineering training. The needs of the industry during the War can lest be met by the continuation of the existing pre-graduate engineering courses. Apart from a small number of the most promising men who can benefit by a special postgraduate course in aeronautics, graduates should proceed at once to aircraft establishments or firms where they can specialize and pull their weight at the earliest possible moment.

\section{Health in Industry}

A MaJor problem brought to the fore during this War has been to bridge the gulf between scientific knowledge and its application. The Industrial Health Research Board has, during the last twenty-five years, published more than eighty reports on industrial conditions in relation to the health and wellbeing of the workers. Unfortunately, the necessity for publishing all the data, so that other workers in this field could know what exactly was the evidence on which the conclusions were based, rendered them of little use to those concerned with organizing industry. To remedy this, pamphlets are to be issued giving the conclusions in more general form, and No. 1, called "Ventilation and Heating; Lighting and Seeing", has just been published (H.M. Stationery Office, price $3 d$ ).

The first part deals with the need for ventilation, the amount of fresh air required, air movement and its problems, some effects of high temperatures, and the complications due to the black-out. The second part gives the principles of good factory lighting, how to measure light, and how the factory regulations should be interpreted, so as to ensure a good general appearance of cheerfulness as well as sulficient light to see the work. Good lighting alone cannot, however, prevent eye-strain for certain kinds of work, so there is a simple account of the working of the muscles of the eyes and of the relief to be secured by the use of special spectacles. There are illustrations showing different systems of artificial lighting, examples of undesirable as well as desirable systems. One undesirable method is called "Glare and Gloom". The pamphlet contains much useful scientific information expressed in readable form.

\section{Measurements at Radio Frequencies}

Following the annual general meeting of the Radio Society of Great Britain held on Decemker 18, Dr. R. L. Smith-Rose gave a lecture on "Measurements in Radio Experimental Work". After referring to the part played by amateur observers and experimenters in sciences such as astronomy and meteorology as well as in radio, Dr. Smith-Rose emphasized the importance of carrying out quantitative measurements in an orderly and systematic manner. A brief review then followed of the present position in the national laboratories of Great Britain and the United States, of the absolute electrical standards of current, inductance and resistance, and of the practical working standards which are derived therefrom. Frequency is one of the absolute electrical standards common to all branches of electrical engineering, from the low frequencies of the power engineer to the highest used in the modern applications of radio technique : and it is noteworthy that the precision of frequency measurement far exceeds that attainable in the determination of any other radio or electrical quality. With the possible exceptions of current and voltage, most measurements at radio frequencies, such as impedance, resistance and reactance, are made by reference to direct current or low-frequency standards. The lecture concluded with a brief description of some investigations illustrating the application of certain types of measurements at radio frequencies to the determination of the mode of transmission of electric waves along the earth's surface.

\section{Determination of Polar Diagrams of Radio Antennæ}

AN article by H. Paul Williams (Elec. Comm., 21, No. 2 ; 1943) describes a machine which enables one to determine a polar diagram in a fraction of the time required by direct calculation. A computation which ordinarily would take a whole day can be performed in fifteen minutes on the machine. In its present version, it will calculate the polar diagram given by as many as five antennæ. These may be situated anywhere within a circle of four wavelengths diameter, while the currents in the antennæe may have any relative phases and magnitudes. The exploring angle is read off from a dial marked in degrees, and the corresponding relative amplitude is shown directly on a voltmeter. As few or as many readings as one likes can ke taken, and also one may turn the handle backwards to a previous value if required.

With such a machine there is an appreciable reduction in the possibilities of errors-a feature quite as important as the saving of time. It is now also practicable to consider a large number of variations in a design the working out of which would take a prohibitive time without such a machine. Although 
the number of antennæ catered for in the present model is five, the principle of operation will allow for its extension to any number. Moreover, the system could readily be extended for tracing out the polar curve automatically. For this refinement all that is required is a turn-table, which would be operated off the common main shaft, and a recording type voltmeter. The machine has been in constant service for about two years.

\section{The Practice of Spraying}

Growmore BuLletin No. 9 ("Orchard Spraying for Commercial Growers". H.M. Stationery Office. Pp. 14. 4d. net) condenses a large amount of modern knowledge into useful practical suggestions for the spraying of fruit trees. Much of the text relates to the routine care of equipment in order to avoid replacement during war-time. Adjustment of the angle of spray cone to give good average coverage without wind loss conserves spray fluid and saves time. Modern research stresses the necessity for highpressure spraying, and the corresponding variations in equipment and practice receive full treatment in the bulletin. Mr. J. Turnbull is the author, and much information about the economics of large-scale spraying is included.

\section{Typhus in Venezuela}

THE May issue of the Boletin de la Oficina Sanitaria Panamericana contains a note on this subject by Dr. L. Briceno-Iragorry, of the Laboratory of Epidemiology of the Venezuela Institute of Hygiene, who states that the first mention of typhus in Venezuela was in March 1896. Since then several cases have been reported in 1938, 1939, 1940 and 1941. The chief forms of the disease in Venezuela may be reduced to two, the first being named Guacaraja fever, which probably resembles Rocky Mountain spotted fever, and the second being known as benign, endemic or rat-borne typhus. The rat-borne character of this second form of typhus has been demonstrated by the Weil-Felix reaction in the blood serum of patients as well as in rats in the Caracas area.

\section{Chronic Parasitoses in Bolivia}

IN a recent paper (Bol. Of. San. Panamericana, 22,487 ; 1943) Dr. Felix Veintemillas, of the Bolivian Institute of Bacteriology at La Paz, states that no systematic study of chronic parasitoses, such as leishmaniasis, yaws, intestinal parasites, dysentery, Chagas's disease and pinto in the tropical and subtropical regions has so far been made, although some progress has been achieved. The Bolivian 'azulejos' has recently been identified with pintos, and the first case of granuloma coccidioides was diagnosed in 1941. So far, however, human cases of Chagas's disease have not been found, but infested vectors have been discovered.

\section{Sir Henry Morris, Bart. (1844-1926)}

SIR HENRY MoRRIS, an eminent London anatomist and surgeon, was born at Petworth, Sussex, on January 7,1844 , the son of a local surgeon. He was educated at Epsom College, of which he afterwards became treasurer, University College, London, and Guy's Hospital, where he qualified in 1861. He first became attached to the Middlesex Hospital in 1870 as surgical registrar, and afterwards became assistant surgeon, then surgeon and in charge of the cancer wards. In 1871 he was lecturer to the Hospital on practical surgery, and during 1872-81 lecturer on anatomy. He retired in 1905 at the age of sixty. He was a prolific writer. His most important work was "The Anatomy of the Joints of Man", which was first published in 1879 and ran through eight editions. In 1893 he became editor of "A Treatise on Human Anatomy", to which he contributed the section on "The Articulations". This work also went through several editions. Besides numerous articles in medical journals and text-books, he was author of several works on genito-urinary surgery. He held many offices at the Royal College of Surgeons, of which the most important were president (1906-7), Hunterian Orator (1909) and member of the Court of Examiners (1894-1904). He died after a short illness on June 14, 1926.

\section{Announcements}

Mr. R. W. Marsh, of the Long Ashton Research Station, has been elected president for 1944 of the British Mycological Society.

A Soviet scientific commission is now in Novosibirsk, organizing a Western Siberian branch of the Academy of Sciences of the U.S.S.R. The Academy will establish four institutes in the city : for chemistry and metallurgy, mining and geology, medicine and biology, and transport and power.

EARL De La WARR, chairman of the Agricultural Research Council and director of home flax production at the Ministry of Supply, is making a tour in Canada to speak to audiences throughout the Dominion about the war-time agricultural effort in Great Britain; he will also visit various agricultural institutions in the Dominion, including research. stations.

A LECTURE on a chemical engineering subject has been endowed by Mr. J. Arthur Reavell, and will be given under the auspices of the Institution of Chemical Engineers. It will be known as "The J. Arthur Reavell Lecture", and will be delivered not less frequently than once in every four years.

THE following appointments have been made in the Colonial Service: B. J. Hancock, agricultural officer, Gold Coast; D. A. McBurney, agricultural officer, Sierra Leone; C. C. Parisinos, agricultural officer, Northern Rhodesia ; R. M. Palmer, assistant conservator of forests, Sierra Leone; J. R. G. Watters, assistant conservator of forests, Nigeria; A. L. C. Thorne, veterinary officer, Gold Coast; C. A. Cockshott, inspector of plants and produce, Gold Coast ; J. H. Henderson, physiological laboratory superintendent, Nigeria ; E. H. Probyn (assistant conservator of forests, Nigeria), assistant conservator of forests, Sierra Leone.

The third conference on "X-Ray Analysis in Industry" has been provisionally arranged to take place in Oxford on March 31 and April 1 under the auspices of the X-Ray Analysis Group of the Institute of Physics. Particulars can be obtained from Dr. H. Lipson, honorary secretary of the Group, c/o Crystallographic Laboratory, Free School Lane, Cambridge. The conference will be open to all interested, but it may be necessary to limit the number of nonmembers of the Group for whom accommodation can be provided. 